\title{
Numerical Analysis of Direct Punch with a View to Velocity and Level of Training
}

\author{
Dora Lapkova, Michal Pluhacek and Milan Adamek \\ Tomas Bata University in Zlin, Faculty of Applied Informatics \\ Department of Security Engineering \\ nám. T.G. Masaryka 5555, 76001 Zlín, CZECH REPUBLIC
}

\begin{abstract}
In this small scale study the possibility of numerical analysis of direct punch velocity is investigated. The aim was to distinguish the level of training of the participants based on the numerical analysis. The measuring devices are described and experiment designed. Different methods of data analysis are proposed and examined. The results are summarized and compared. Promising trends are highlighted. It is concluded that some aspect of the numerical analysis seem promising for future use for level of training classification.
\end{abstract}

Keywords: Direct punch, Professional defence, Level of training, Velocity, High-speed camera.

\section{INTRODUCTION}

The striking techniques (punches and kicks) are one of the basic elements of the majority of combat sports [2], martial arts [5] or combat systems [9]. In these techniques the striking energy [8] is typically transferred through arms, legs or head. The direct punch is delivered in such manner that the arm follows a direct line. The hitting area is a closed fist [11]. The purpose is to stop the attacker and also to increase distance between the defender and the attacker. In the following experiment the punch was delivered by the back hand (See FIGURE 1.).

In this initial study the direct punch velocity is closely analyzed. The aim was to measure the velocity of direct punch and further to find out whether there are any dependencies of velocity on level of training of the participant.



FIGURE 1. Direct punch [11]

\section{MEASURING STATION}

A high-speed camera Olympus i-Speed 2 was used for measuring of velocity. This camera has CMOS 800x600 sensor, full resolution recordings to $1000 \mathrm{fps}(\mathrm{fps}=$ frames per second) and $33000 \mathrm{fps}$ maximum recording speed. We used recording speed 1000 fps $[1,6,10]$.

During this experiment we used only one camera, so we choose direct punch from all striking techniques because only this punch is made directly. The result is that during the whole movement of the hand we have had a focused image.

The measuring station consists of a punching bag and a construction of its suspension. Paper with two perpendicular lines was stuck on the right of the punching bag. Horizontal line was for leading the hand during movement. The aim of the vertical line was to determine the beginning of data analysis. The result was that the all direct punches were measured in the same distance from punching bag. This distance was $60 \mathrm{~mm}$. The end of the measuring was at the moment when the movement of the hand was stopped in axis " $\mathrm{x}$ " - the deformation of punching bag was at the maximum. 




FIGURE 2. Measuring station

\section{EXPERIMENT}

The total of 30 participants took part in the experiment; 24 men and 6 women. Based on the previous training the participants were divided into following three groups:

$>$ Untrained - These people have never done any combat sport, martial art or combat system. They have no theoretical knowledge of the striking technique. The technique was presented to these people before the experiment for safety reasons. Noted further as UTM (for men).

$>$ Mid-trained - These people have the theoretical knowledge of striking techniques and they have attended the Special physical training course for at least six months. The course is focused on self-defence and professional defence. Noted further as MTM (for men) and MTW (for women).

$>$ Trained - These people do some combat sports, martial arts or a combat system for longer than two years. Noted further as TM (for men).

During the experiment each person made one strike (Except one man from training group. He did two strikes.). During the measurement the target was positioned in such manner that the center of the punching bag was in line with the striking person's shoulder. That way the punches have the maximum velocity and force (as there is no decomposition of force or velocity into the other axes). The person was made to stay at the same place for the whole experiment. Any unnecessary movement (e. g. lunge etc.) would lead to data distortion.

Reflective markers with diameter $10 \mathrm{~mm}$ have been stuck on the hand of each person.

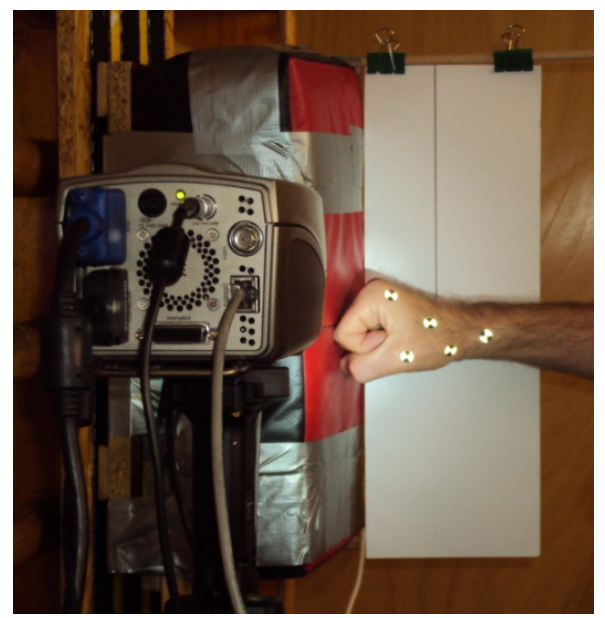

FIGURE 3. Reflective markers 


\section{NUMERICAL ANALYSIS AND RESULTS}

For data analysis the i-Speed Control Software was used. It is used for image analysis and for image processing modification of contrast, brightness etc. On the basis of sequential labeling of markers on hand the software it is able to calculate the velocity of the hand. The rate of images (1000 fps) and the distance of markers between two images are known.

The MINITAB software was used for velocity analysis.

There were four categories of data analysis:

$>$ Version A: We used all data from measuring - the beginning of measuring was in distance of $60 \mathrm{~mm}$ in front of the punching bag, the end was at the moment when the movement of the hand has stopped in axis " $x$ " (the deformation of punching bag was at the maximum).

$>$ Version B: We used only 20 values - the beginning of measuring was in distance of $60 \mathrm{~mm}$ in front of punching bag, the end was after 20 sequence values.

$>$ Version C: We used data after first hand contact with punching bag - the beginning of measuring was at the moment when the closed fist made a contact with punching bag. The end was at the moment when the movement of the hand has stopped in axis " $x$ " (the deformation of punching bag was at the maximum).

$>$ Version D: We used only 20 values after first contact of hand with punching bag - the beginning of measuring was at the moment when the closed fist made a contact with punching bag, the end was after 20 values.

The results are presented in Tables $1-4$. In the following tables the promising trends are highlighted by bold values. As promising it is understood that the higher is the level of training the higher is the actual value of the numerical expression.

TABLE 1. Version A - mean values for category (by level of training)

\begin{tabular}{cccccc}
\hline & Mean & StDev & CoefVar & Minimum & Maximum \\
\hline UTM & 3,169 & $\mathbf{1 , 6 2 6 9}$ & 51,85 & 0,836 & $\mathbf{5 , 9 8 9}$ \\
MTM & 2,848 & $\mathbf{1 , 8 6 3 1}$ & 65,65 & 0,485 & $\mathbf{6 , 3 2 5}$ \\
TM & 4,203 & $\mathbf{2 , 5 4 5 0}$ & 60,13 & 0,727 & $\mathbf{8 , 1 0 9}$ \\
MTX & 2,022 & $\mathbf{1 , 2 3 9 0}$ & 61,05 & 0,449 & $\mathbf{4 , 3 4 7}$ \\
\hline
\end{tabular}

TABLE 2. Version B - mean values for category (by level of training)

\begin{tabular}{cccccc}
\hline & Mean & StDev & CoefVar & Minimum & Maximum \\
\hline UTM & $\mathbf{3 , 9 6 4}$ & $\mathbf{1 , 3 2 2 0}$ & 34,20 & $\mathbf{1 , 9 8 3}$ & $\mathbf{5 , 9 8 9}$ \\
MTM & $\mathbf{4 , 3 5 5}$ & $\mathbf{1 , 3 5 5 8}$ & 31,27 & $\mathbf{2 , 4 7 5}$ & $\mathbf{6 , 3 2 5}$ \\
TM & $\mathbf{5 , 7 7 6}$ & $\mathbf{1 , 8 5 6 0}$ & 31,66 & $\mathbf{2 , 8 8 0}$ & $\mathbf{8 , 1 0 9}$ \\
MTX & $\mathbf{2 , 8 3 2}$ & $\mathbf{1 , 0 1 9 5}$ & 35,64 & $\mathbf{1 , 4 6 3}$ & $\mathbf{4 , 3 4 7}$ \\
\hline
\end{tabular}

TABLE 3. Version $\mathrm{C}-$ mean values for category (by level of training)

\begin{tabular}{cccccc}
\hline & Mean & StDev & CoefVar & Minimum & Maximum \\
\hline UTM & 2,865 & 1,4469 & 50,62 & 0,835 & 5,736 \\
MTM & 2,324 & 1,4458 & 62,29 & 0,485 & 5,658 \\
TM & 3,593 & 2,1850 & 60,02 & 0,727 & 7,751 \\
MTX & 2,865 & 1,4469 & 50,62 & 0,835 & 5,736 \\
\hline
\end{tabular}


TABLE 4. Version D - mean values for category (by level of training)

\begin{tabular}{cccccc}
\hline & Mean & StDev & CoefVar & Minimum & Maximum \\
\hline UTM & 3,328 & $\mathbf{1 , 3 0 9 9}$ & 39,52 & $\mathbf{1 , 6 1 8}$ & 5,736 \\
MTM & 3,220 & $\mathbf{1 , 1 8 3 2}$ & 37,08 & $\mathbf{1 , 6 2 8}$ & 5,658 \\
TM & 4,520 & $\mathbf{1 , 8 5 0 0}$ & 40,37 & $\mathbf{1 , 9 6 2}$ & 7,751 \\
MTX & 1,925 & $\mathbf{0 , 8 5 6 0}$ & 44,81 & $\mathbf{0 , 9 2 0}$ & 3,808 \\
\hline
\end{tabular}

\section{CONCLUSION}

In this paper it was investigated the possibilities of applying numerical analysis on the direct punch velocity data. Experiments were undertaken in order to collect the data and several ways of the data analysis were investigated. Based on the presented results it seems that the most promising approach is the version B (Table b). There are very promising trends and correlations between the numerical values and the level of training These promising results will be analyzed further in the future research that will include higher number of participants and more extensive data analysis.

\section{ACKNOWLEDGMENTS}

This work was supported by the Internal Grant Agency at TBU in Zlín, project No. IGA/FAI/2014/036, IGA/FAI/2014/010 and by the European Regional Development Fund under the project CEBIA-Tech No. CZ.1.05/2.1.00/03.0089.

\section{REFERENCES}

1. M. Baroň, Measurement and evaluation of high-speed processes using high-speed camera system Olympus i-SPEED 2. Zlín, 2010. Thesis. Tomas Bata University in Zlin. Advisor doc. Dr. Ing. Vladimír Pata

2. G. Blower, Boxing: Training, Skills and Techniques. Crowood, 2007

3. R. P. Bolander, O. P. Neto and C. A. Bir, The effects of height and distance on the force production and acceleration in martial arts strikes. Journal of Sports Science and Medicine [online]. 2009, roč. 8, s. 47-52 [cit. 2012-06-27]. Available: $\mathrm{http} / / / \mathrm{www}$.jssm.org/combat/3/9/v8combat3-9.pdf

4. H. Chiu and T. Shiang, A NEW APPROACH TO EVALUATE KARATE PUNCH TECHNIQUES. [online]. [cit. 2012-06-27]. Available: http://w4.ub.uni-konstanz.de/cpa/article/viewFile/4052/3751

5. C. Gianino, Physics of Karate: Kinematics analysis of karate techniques by a digital movie camera. Latin-American Journal of Physics Education, 2010, 4.1: 5

6. P. Kolomaznik, Methodology of fast and stochastic mechanical process research. Brno, 2008. Thesis. Brno University of Technology. Advisor doc. Dr. Ing. Vladimír Pata

7. D. Lapkova, M. Pluhacek and M. Adamek, Computer Aided Analysis of Direct Punch Force Using the Tensometric Sensor. In: Modern Trends and Techniques in Computer Science: 3rd Computer Science On-line Conference 2014 (CSOC 2014). Springer, 2014, s. 507-514. ISBN 978-3-319-06739-1.ISSN 2194-5357

8. D. Lapkova, M. Pospisilik, M. Adamek and Z. Malanik, The utilisation of an impulse of force in self-defence. In: $X X$ IMEKO World Congress: Metrology for Green Growth.Busan, Republic of Korea, 2012, ISBN: 978-89-950000-5-2

9. D. Levine, J. Whitman, Complete Krav Maga. 2007

10. J. Pešek, High speed digital imaging system I-Speed 2 and its application. Brno, 2008. Bachelor's thesis. Brno University of Technology. Advisor doc. Dr. Ing. Vladimír Pata

11. Z. Reguli, Inovace SEBS a ASEBS: Inovace bakalářského studijného oboru Speciální edukace bezpečnostních složek a navazujícího magisterského studijního oboru Aplikovaná sportovní edukace bezpečnostních složek. BIOMECHANIKA ÚPOLOVÝCH SPORTÜ A BOJOVÝCH UMÉNÍ [online]. 2011, Available: http://www.fsps.muni.cz/inovace-SEBSASEBS/elearning/biomechanika/biomechanika-upolovych-sportu 
AIP Conference Proceedings is copyrighted by AIP Publishing LLC (AIP). Reuse of AIP content is subject to the terms at: http://scitation.aip.org/termsconditions. For more information, see http://publishing.aip.org/authors/rights-and-permissions. 